\title{
Sorption capacity of Indian coal and its variation with rank parameters
}

\author{
Harinandan Kumar $^{1} \cdot$ M. K. Mishra ${ }^{1} \cdot$ S. Mishra ${ }^{2}$ \\ Received: 6 October 2018 / Accepted: 7 February 2019 / Published online: 15 February 2019 \\ (c) The Author(s) 2019
}

\begin{abstract}
The study of gas sorption characteristics is important for practical assessment of coal bed methane (CBM) production and $\mathrm{CO}_{2}$ sequestration in coal seam. Adsorption isotherm is one of the critical parameters for the establishment of production as well as injection well. Adsorption isotherm provides information about the reservoir conditions and critical desorption pressure as well as volume of gas that can be sequestered in deep coal seam. Alteration in sorption isotherm reflects the increase or decrease of the gas production as well as $\mathrm{CO}_{2}$ sequestration. Therefore, in this paper, experimental investigation was carried out to determine the $\mathrm{CO}_{2} / \mathrm{CH}_{4}$ sorption capacity of five different coal samples taken from different locations of Jharia coalfield (Moonidih area) of Gondwana basin. Gas sorption capacity was determined at $27{ }^{\circ} \mathrm{C}$ temperature and up to 7.5 MPa pressure. $\mathrm{CO}_{2}$ adsorption was observed to be higher than that of the $\mathrm{CH}_{4}$. The sorption ratio of $\mathrm{CO}_{2} / \mathrm{CH}_{4}$ varied from 1.6:1 to 1.2:1 for all coal samples. Furthermore, the experimental results were correlated using established Langmuir, Freundlich, Temkin and D-R isotherm models. Experimentally obtained values satisfactorily fitted to the Langmuir and Freundlich model with comparable accuracy. The excess adsorption capacity of coal was also compared with different rank parameters to understand the variation of sorption capacity with rank of coal.
\end{abstract}

Keywords Coal bed methane $\cdot$ Proximate and ultimate analyses $\cdot \mathrm{CO}_{2} / \mathrm{CH}_{4}$ sorption capacity $\cdot$ Statistical analysis

\section{Introduction}

At present, climate change and global warming are the most debated topics. $\mathrm{CO}_{2}$ is one of the dominant causes of greenhouse gas effect (GHG) and global warming due to its higher concentration in the atmosphere. Thermal generation capacity of India will be $290 \mathrm{GW}$ in 2047, out of which $253 \mathrm{GW}$ will be coal based and $37 \mathrm{GW}$ gas based (1). Increasing demand of energy also increases $\mathrm{CO}_{2}$ emission. Concentration of $\mathrm{CO}_{2}$ in the atmosphere was found to be $396 \mathrm{ppmv}$ in 2013 which was $40 \%$ higher than that in mid-1800s (2). The rate of emission was 2 ppmv/year for the last 10 years (2) alarming the world for advancement towards technology for the reduction of $\mathrm{CO}_{2}$ concentration in atmosphere. The $\mathrm{CO}_{2}$ concentration can be controlled by two ways: one to reduce $\mathrm{CO}_{2}$ emissions into the atmosphere and the other to reduce

Harinandan Kumar

harinandankumar88@gmail.com

1 Department of Mining Engineering, NIT Rourkela, Rourkela, Odisha 769008, India

2 Department of Chemical Engineering, NIT Rourkela, Rourkela, Odisha 769008, India the present concentration of $\mathrm{CO}_{2}$ in the atmosphere to safe levels through application of various engineering principles. The second way is possible by $\mathrm{CO}_{2}$ storage in un-minable coal seams, depleted oil and gas reservoirs, abandoned and sealed mines, saline aquifers, oceans, etc. (Ishaq et al. 2009; Shi and Durucan 2005; Robertson 2010). Sequestration of $\mathrm{CO}_{2}$ in deep coal seam is one of the techniques to reduce $\mathrm{CO}_{2}$ concentration in the atmosphere and mitigation of global warming. Coal bed reservoir has the ability to store and retain large quantity of $\mathrm{CO}_{2}$ gas for very long time due to its porous nature (Shi and Durucan 2005; Robertson 2010). Injection of $\mathrm{CO}_{2}$ in coal seam also facilitates beneficial effect on enhanced coal bed methane recovery (ECBM) (Stevens et al. 1998; Seidle 2000; Pagnier et al. 2005). Estimation of $\mathrm{CO}_{2} / \mathrm{CH}_{4}$ sorption in deep coal seam requires critical experimental investigation (Hernandez et al. 2006; Vishal et al. 2015; Buscha and Gensterblumb 2011). Investigative effort has been undertaken elsewhere to estimate excess sorption capacity at different temperature and increasing pressure values (13; Prusty 2008; Chen et al. 2011). $\mathrm{CO}_{2} / \mathrm{CH}_{4}$ sorption ratio was reported to be 10:1 for low-rank coal and less than 2:1 for low- and medium-volatile bituminous coals (Deng et al. 2015). Variation in gas sorption capacity of coal based 
on proximate analysis, ultimate analysis and maceral contents has been reported elsewhere (Saikia and Sarkar 2013; Ghosh et al. 2014). The sorption isotherm gives estimated retention capacity of gas at in situ temperature and pressure of reservoir. Detailed sorption isotherm of $\mathrm{CO}_{2}$ and $\mathrm{CH}_{4}$ is required as input for production simulation in $\mathrm{CBM}$ and ECBM operations (Ghosh et al. 2014). The investigation suggests the variation of rate of sorption depends upon the pore size and porosity of the coal, molecular size of the gas and critical temperature and pressure (19; Suman and Harpalani 2019; Ali et al. 2018).

In this investigation, the sorption capacity of $\mathrm{CO}_{2}$ and methane on five different coal samples (namely JH-MD-S JH-MD-S ${ }_{2}$, JH-MD- $\mathrm{S}_{3}$, JH-MD-S 4 and JH-MD-S $_{5}$ from Jharia coalfield (Moonidih area) was carried out experimentally. Excess $\mathrm{CO}_{2} / \mathrm{CH}_{4}$ sorption capacity was obtained at $27^{\circ} \mathrm{C}$ with incremental gas pressure from 0 to $7.5 \mathrm{MPa}$ at varying depth from 400 to $580 \mathrm{~m}$. Sorption isotherms were plotted using experimentally obtained values. The experimentally obtained data were compared with four different established isotherm models, namely (Langmuir, Freundlich, Temkin and $\mathrm{D}-\mathrm{R}$ isotherm models) to obtain the best-fit isotherm model for the study area. The rank parameters such as moisture content, ash content, volatile matter (daf basis), fixed carbon (daf basis) and vitrinite reflectance were correlated with $\mathrm{CO}_{2}$ and $\mathrm{CH}_{4}$ excess sorption amount to determine the effect of these parameters on sorption amount of coal.

\section{Geological setting of Jharia coal bed basin}

Coal sample for the sorption study was collected from the underground mine of Jharia coal bed basin (Moonidih Area) (Fig. 1) which is located in Dhanbad district of Jharkhand, India. It is bounded between $23^{\circ} 37^{\prime} \mathrm{N}$ and $23^{\circ} 52^{\prime} \mathrm{N}$ and longitudes $86^{\circ} 05^{\prime} \mathrm{E}$ and $86^{\circ} 30^{\prime} \mathrm{E}$. Mostly these mines are full of gassy environment with elevated strata temperature (Daniel and Bustin 2007) (Guo 2003).

\section{Sample preparation and experimentation}

The sorption study was carried out on coal samples obtained from freshly exposed coal surface at depth varying from 400 to $580 \mathrm{~m}$. The lump of samples was crushed and passed through a sieve of size 72 BSS mesh $(212 \mu \mathrm{m})$. The moisture content of the samples was estimated as per standard [ASTM D 3173-11]. Proximate analysis of these samples was estimated as per the standard method [ASTMD 3172-07a] and ultimate analysis using CHNS Analyzer [Make Evisa Vario EL III- CHNS analyzer] as per the standard methods [ASTM D 3176-09].

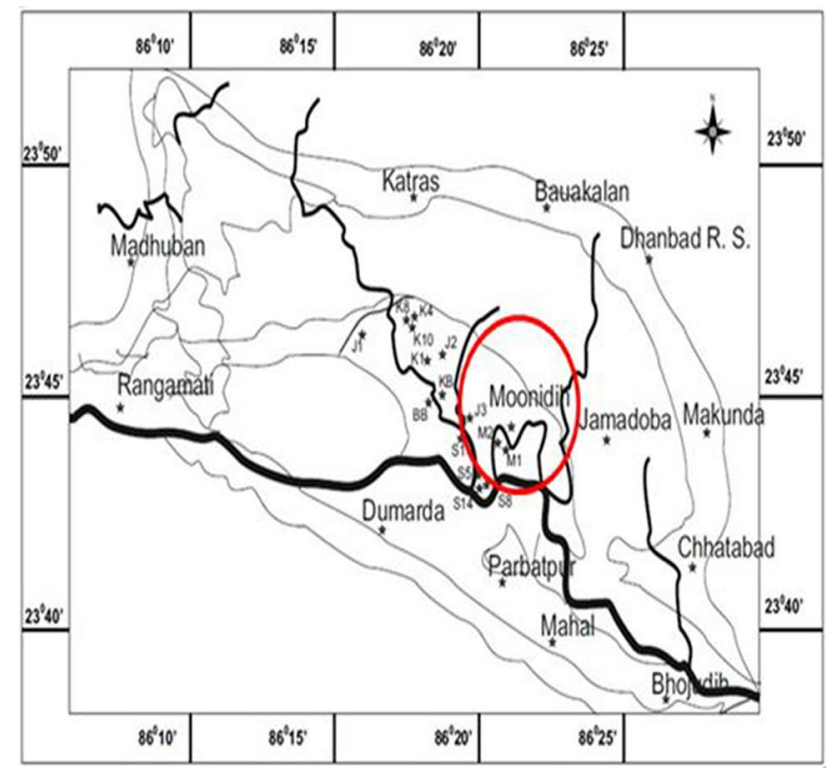

Fig. 1 Geological setting of Jharia coalfield (Moonidih area)

Volumetric sorption setup was used to estimate the sorption capacity of coal. The setup consists of reference cell, sample cell, flow line, digital pressure transducer, data acquisition system, etc. (Figs. 2,3). The volumetric setup was kept immersed in water bath maintained at uniform temperature of $27{ }^{\circ} \mathrm{C}$ $\left( \pm 1^{\circ} \mathrm{C}\right)$. The volume of excess sorption was determined at constant temperatures as a function of pressure at equilibrium.

\section{Determination of sorption capacity}

About $100 \mathrm{~g}$ of coal sample was taken in the calibrated sample cell. The setup was evacuated to remove unwanted gas present in coal using vacuum pump (make: Scientific Instrument Services, Inc., USA). Helium gas was injected at $0.68-3.5 \mathrm{MPa}$ pressure to determine the volume of sample as well as reference cell using volume expansion method as follows (Zhang et al. 2013):

$V_{\mathrm{s}}=\frac{\psi}{\psi-\xi} \times V_{\mathrm{sb}}$,

$\psi=\frac{\frac{P_{\mathrm{s}_{2}}}{Z_{\mathrm{s}_{2}}}-\frac{P_{\mathrm{s}_{1}}}{Z_{\mathrm{s}_{1}}}}{\frac{P_{\mathrm{r}_{1}}}{Z_{\mathrm{r}_{1}}}-\frac{P_{\mathrm{r}_{2}}}{Z_{\mathrm{r}_{2}}}}$,

$\xi=\frac{\frac{P_{\mathrm{s}_{2}}}{Z_{\mathrm{s}_{2}}}-\frac{P_{\mathrm{s}_{1}}}{Z_{\mathrm{s}_{1}}}}{\frac{P_{\mathrm{r}_{1}}}{Z_{\mathrm{r}_{1}}}-\frac{P_{\mathrm{r}_{2}}}{Z_{\mathrm{r}_{2}}}}$, 


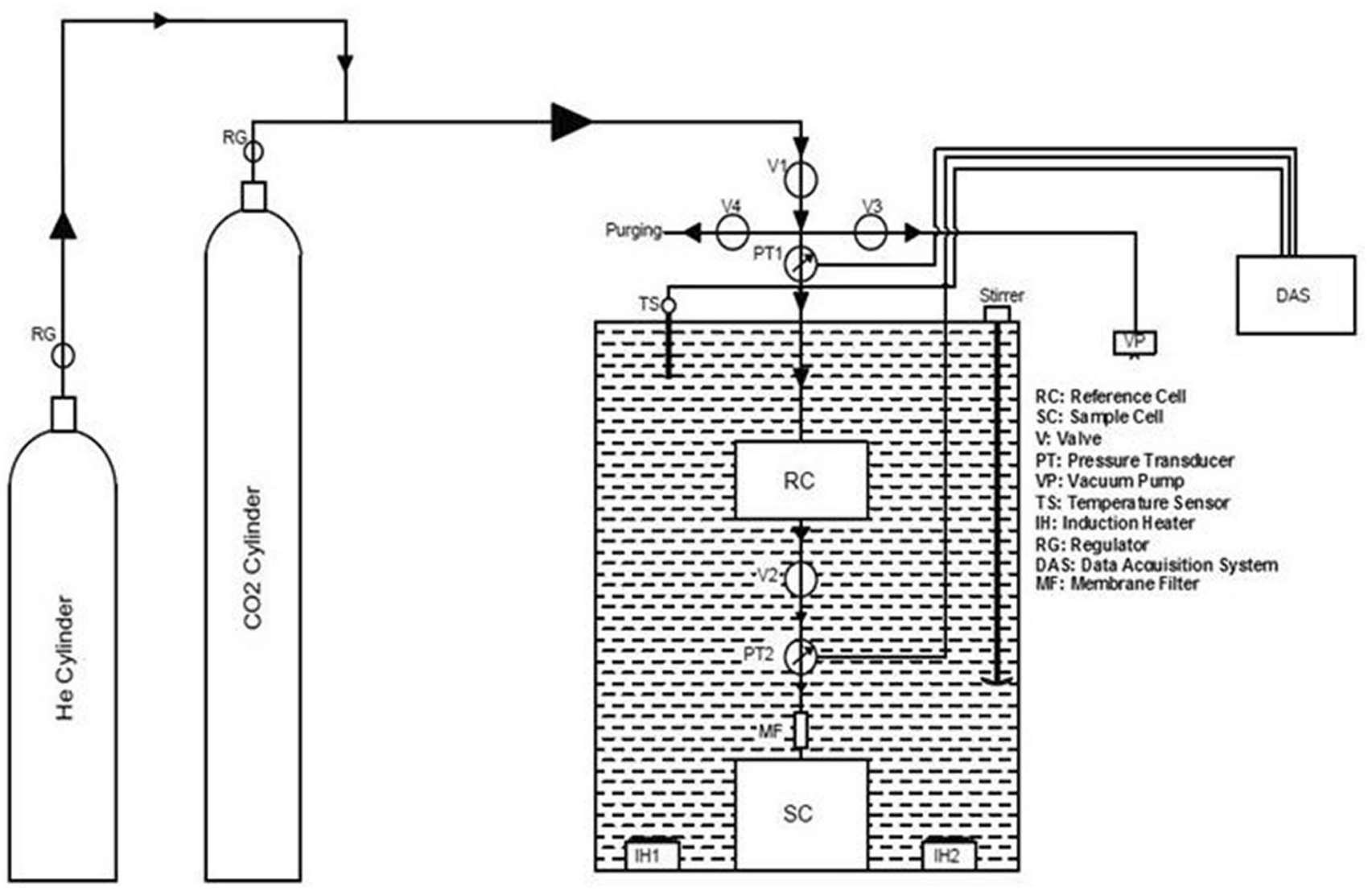

Fig. 2 Schematic diagram of volumetric sorption setup

where $V \mathrm{~s}$ is the volume of sample cell, $\psi$ is the constant with iron ball in the sample cell, $\xi$ is the constant without iron ball in sample cell, $V_{\mathrm{sb}}$ is the total volume of the iron ball, $P_{\mathrm{s} 2}$ and $P_{\mathrm{s} 1}$ are the pressure of helium gas in sample cell before and at the equilibrium condition, $P_{\mathrm{r} 2}$ and $P_{\mathrm{r} 1}$ are the pressure of helium gas in reference cell before and at the equilibrium condition, $Z_{\mathrm{s} 2}, Z_{\mathrm{s} 1}, Z_{\mathrm{r} 2}, Z_{\mathrm{r} 1}$ are the compressibility factor at the respective pressure. Similarly, the volume of reference cell was determined as (Zhang et al. 2013):

$V_{\mathrm{r}}=\frac{\psi \times \xi}{\psi-\xi} \times V_{\mathrm{sb}}$.

Compressibility factor was calculated using American gas association report no. 8, 1992 (GAS Calc.5.0). Void volume $\left(V_{\mathrm{v}}\right)$ was calculated as (Zhang et al. 2013):

$V_{\mathrm{v}}=\frac{\frac{P_{\mathrm{r}_{1}}}{Z_{\mathrm{r}_{1}}}-\frac{P_{\mathrm{r}_{2}}}{Z_{\mathrm{r}_{2}}}}{\frac{P_{\mathrm{s}_{2}}}{Z_{\mathrm{s}_{2}}}-\frac{P_{\mathrm{s}_{1}}}{Z_{\mathrm{s}_{1}}}} \times V_{\mathrm{r}}$.

Mole transferred was determined as

$n_{\text {total }}=\frac{P_{\mathrm{r}} V_{\mathrm{r}}}{Z_{\mathrm{r}} \mathrm{RT}}$ where $n_{\text {total }}$ is the mole transferred to the reference cell, $R$ is the gas constant and $T$ is the temperature at which the experiment was conducted $\left(27^{\circ} \mathrm{C}\right)$.

$\mathrm{CO}_{2}$ gas (99.99\% pure) was first filled in the reference cell at regular interval of $0.68 \pm 0.068 \mathrm{MPa}$.

Total mole transferred to the reference cell was determined as (Zhang et al. 2013):

$n_{\mathrm{r}}=\frac{\frac{P_{\mathrm{r}_{1}}}{Z_{\mathrm{r}_{1}}}-\frac{P_{\mathrm{r}_{2}}}{Z_{\mathrm{r}_{2}}}}{R \times T} \times V_{\mathrm{r}}$,

$n_{\mathrm{s}}=\frac{\frac{P_{\mathrm{s}_{2}}}{Z_{\mathrm{s}_{2}}}-\frac{P_{\mathrm{s}_{1}}}{Z_{s_{1}}}}{R \times T} \times V_{\mathrm{s}}$.

The sorption of gas was estimated through mole balance. Gas adsorbed was determined from the difference between mole injected and mole present in void:

$n_{\text {adsorbed }}=n_{\text {injected }}-n_{\text {void }}$. 

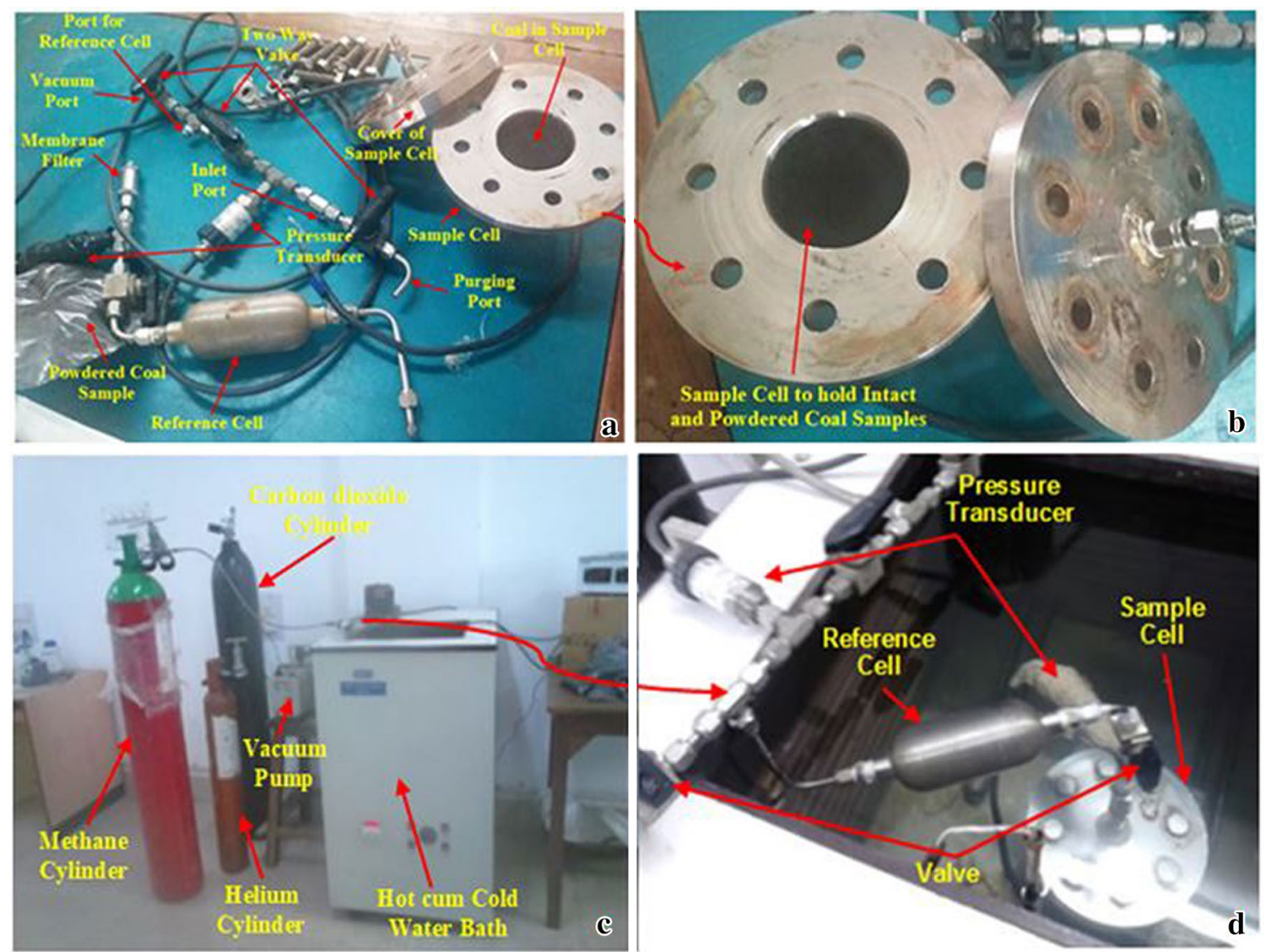

Fig. 3 Experimental setup for sorption test. a Detailed view of the different parts in setup. b Sample cell to hold intact as well as powdered coal samples. c Setup with gas cylinder as well as vacuum pump. d Setup in place

\section{Results and discussion}

The results of proximate and ultimate analyses are shown in Table 1. VM (daf basis) varies between 21.02 and 34.48, while FC (daf basis) found in between 65.52 and 78.98 indicates medium-volatile bituminous coal. Variation in moisture and ash content from 0.93 to 1.4 and 9.01 to 20.64 reflects medium-volatile bituminous coal. Value of vitrinite reflectance was determined using the established Rice formula (Rice 1993) as.

$R_{0}(\%)=-2.712 \times \log \left(V M_{\text {daf }}\right)+5.092$,

where $R_{0}$ is the vitrinite reflectance (\%) and $\mathrm{VM}_{(\mathrm{daf})}$ is the volatile matter (dry ash-free basis) (\%).
Table 1 Results of proximate analysis of coal samples

\begin{tabular}{llllll}
\hline Parameters & \multicolumn{5}{l}{ Sample ID } \\
\cline { 2 - 6 } & JH-MD-S & JH-MD-S & JH-MD-S & JH-MD-S $_{4}$ & JH-MD-S $_{5}$ \\
\hline Depth (m) & 580 & 520 & 500 & 450 & 400 \\
M (wt\%) & 0.93 & 1.19 & 1.27 & 1.28 & 1.40 \\
A (wt\%) & 9.01 & 13.46 & 15.38 & 18.49 & 20.64 \\
VM (wt\%) & 18.93 & 22.53 & 24.81 & 25.28 & 26.88 \\
FC (wt\%) & 71.13 & 62.82 & 58.54 & 54.95 & 51.08 \\
VM (d) (wt\%) & 19.11 & 22.80 & 25.13 & 25.61 & 27.26 \\
FC (d) (wt\%) & 71.80 & 63.58 & 59.29 & 55.66 & 51.81 \\
VM (daf) (wt\%) & 21.02 & 26.40 & 29.77 & 31.51 & 34.48 \\
FC (daf) (wt\%) & 78.98 & 73.60 & 70.23 & 68.49 & 65.52 \\
R0 (\%) & 1.51 & 1.24 & 1.10 & 1.03 & 0.92 \\
\hline
\end{tabular}


Table 2 Sorption capacity of coal

\begin{tabular}{|c|c|c|c|}
\hline \multirow[t]{2}{*}{ Samples } & \multirow[t]{2}{*}{ Depth (m) } & \multicolumn{2}{|c|}{$\begin{array}{l}\text { Excess sorption amount } \\
(\mathrm{cc} / \mathrm{g})\end{array}$} \\
\hline & & $\mathrm{CO}_{2}$ & $\mathrm{CH}_{4}$ \\
\hline JH-MD-S & 580 & 20.52 & 13.29 \\
\hline JH-MD-S 2 & 520 & 16.54 & 12.29 \\
\hline JH-MD-S 3 & 500 & 14.26 & 11.23 \\
\hline JH-MD-S 4 & 450 & 10.02 & 9.99 \\
\hline JH-MD-S ${ }_{5}$ & 400 & 11.11 & 9.49 \\
\hline
\end{tabular}

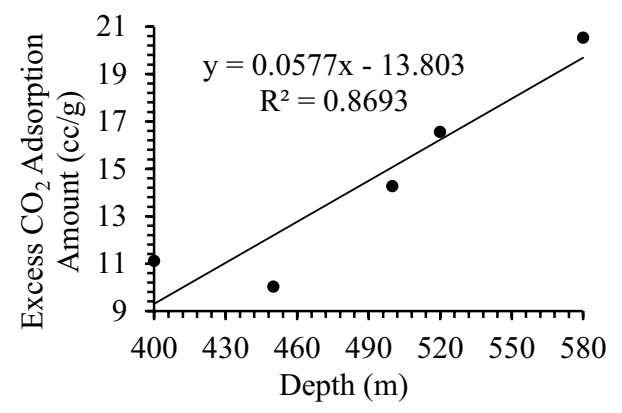

Fig. 4 Variation of excess $\mathrm{CO}_{2}$ sorption with depth

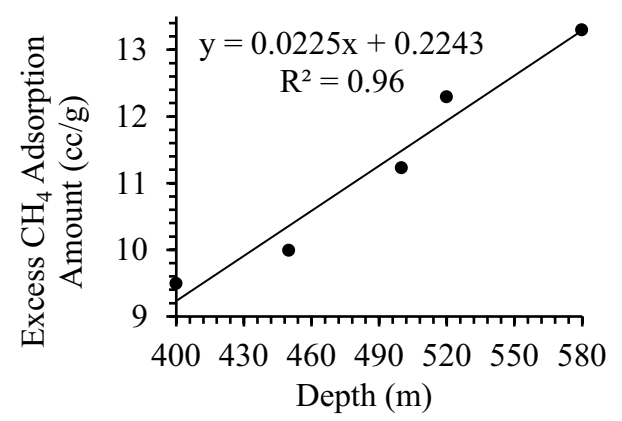

Fig. 5 Variation of excess $\mathrm{CH}_{4}$ sorption with depth
The variation of $R_{0}$ between 0.92 and 1.51 indicates medium-volatile bituminous coal as per the rank parameter discussed elsewhere (Diessel 1992) (Table 1). The values of vitrinite reflectance observed in this study lie in between the threshold value of $0.7-2.0 \%$ which confirms commercial CBM prospects as described elsewhere (Chandra 1950).

\section{Sorption capacity of coal bed}

Sorption capacity was measured at the highest pressure of 7.5 $\mathrm{MPa}$ for methane and 5.5 $\mathrm{MPa}$ for $\mathrm{CO}_{2}$ at $300 \mathrm{~K} . \mathrm{CO}_{2}$ and $\mathrm{CH}_{4}$ sorption capacity varied from 11.11 to 20.52 and 9.49 to $13.29 \mathrm{cc} / \mathrm{g}$, respectively (Table 2). Sharp increase in sorption capacity was observed with increase in depth of coal seam (Figs. 4, 5). Increase in sorption capacity with depth is due to the increase in carbon content as well as porosity of coal and reduction in moisture content. The sorption ratio of $\mathrm{CO}_{2} / \mathrm{CH}_{4}$ was from 1.6:1 to 1.2:1. Adsorption of $\mathrm{CO}_{2}$ was observed to be higher than that of $\mathrm{CH}_{4}$ with an increase in pressure. The difference between adsorption amounts is due to the higher density of $\mathrm{CO}_{2}$ and its interaction with coal than that with $\mathrm{CH}_{4}$. It is also due to the variation in molecular diameter of $\mathrm{CO}_{2}(0.33 \mathrm{~nm})$ than $\mathrm{CH}_{4}$ $(0.38 \mathrm{~nm})$. This increase in maturity and higher rank of coal allow more sorption. $\mathrm{CO}_{2}$ sorption capacity of coal of study area was also compared with different coalfields worldwide (Table 3).

\section{Determination of sorption isotherm based on experimental data}

The sorption capacity of $\mathrm{CO}_{2}$ and $\mathrm{CH}_{4}$ in coal was studied and sorption isotherm was plotted (Figs. 6, 7). Experimental values were compared with other isotherm models such as D-R, Temkin, Freundlich and Langmuir, respectively, using linear regression method. Values were analysed statistically to determine the regression coefficient of all isotherm

Table 3 Sorption capacity of coal at different coalfields worldwide

\begin{tabular}{|c|c|c|c|c|c|}
\hline Location & Depth (m) & Temp. $\left({ }^{\circ} \mathrm{C}\right)$ & Pressure (bar) & $\begin{array}{l}\text { Excess sorption } \\
\text { amount }(\mathrm{cc} / \mathrm{g})\end{array}$ & References \\
\hline Monte Sinni coal mine (Carbosulcis, Cagliari, Italy) & 500 & 45 & 190 & 45.302 & (Mares et al. 2009) \\
\hline Huntly Coalfield, New Zealand & 520 & 32 & 40 & 23.718 & (Gruszkiewicz et al. 2009) \\
\hline Black Warrior Basin, West Central Alabama & 731 & 35 & 69 & 17.968 & (Saghaf 2010) \\
\hline Australian coals & 750 & 27 & 51 & 24.998 & $(31)$ \\
\hline Great Britain, Slovenia and Poland & - & 45 & 69 & 39.754 & (Garnier et al. 2011) \\
\hline \multirow[t]{2}{*}{ Kyungdong coal (South Korea) } & 756 & 65 & 101 & 27.401 & $(33)$ \\
\hline & & 45 & 76 & 33.016 & \\
\hline \multirow[t]{2}{*}{ Waterberg Coalfield, South Africa } & 250 & 30 & 45 & 44.471 & (Maphala 2012) \\
\hline & & 30 & 42 & 20.910 & \\
\hline Jharia Coalfield, India & 580 & 27 & 55 & 20.52 & Study area \\
\hline
\end{tabular}


Fig. 6 a Comparison of $\mathrm{CO}_{2}$ excess sorption amount of different coals at $27^{\circ} \mathrm{C}$. b Comparison of different $\mathrm{CO}_{2}$ sorption isotherm models at $580 \mathrm{~m}$ depth and $27^{\circ} \mathrm{C}$
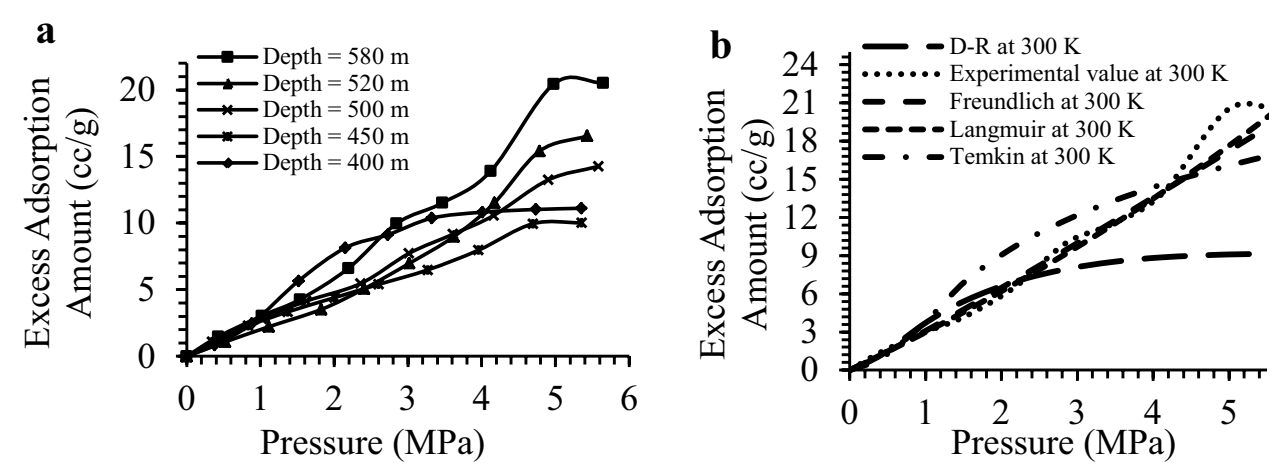

Fig. 7 a Comparison of $\mathrm{CH}_{4}$ excess sorption amount of different coals at $27^{\circ} \mathrm{C}$. b Comparison of different $\mathrm{CH}_{4}$ sorption isotherm models at $580 \mathrm{~m}$ depth and $27^{\circ} \mathrm{C}$

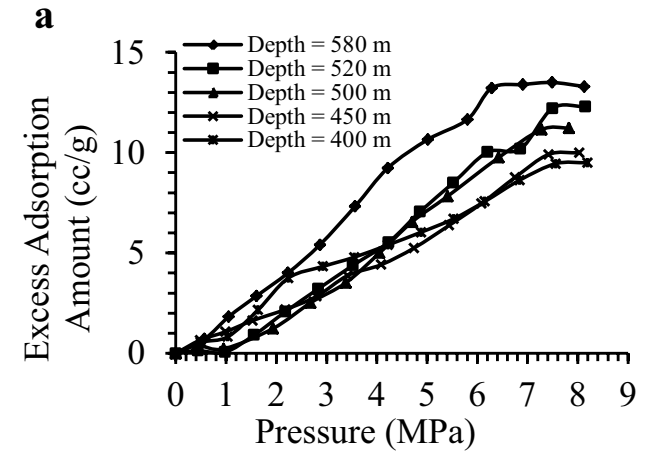

Table 4 Constant of $\mathrm{CO}_{2}$ sorption isotherm model at $27^{\circ} \mathrm{C}$

\begin{tabular}{llllll}
\hline Depth $(\mathrm{m})$ & \multicolumn{2}{l}{ Freundlich isotherm } & & \multicolumn{2}{c}{ Langmuir isotherm } \\
\cline { 2 - 3 } \cline { 6 - 6 } & $1 / n$ & $K_{\mathrm{f}}$ & & $q_{\mathrm{m}}$ & $K$ \\
\hline 580 & 0.9693 & 0.0151 & & 76.9230 & 0.000257 \\
520 & 1.2061 & 0.0049 & & 21.0970 & 0.000565 \\
500 & 0.9693 & 0.0208 & & 30.3951 & 0.000669 \\
450 & 0.818 & 0.0438 & & 28.9017 & 0.000647 \\
400 & 0.5153 & 0.0208 & & 14.7928 & 0.004244 \\
\hline
\end{tabular}

Table 5 Constant of $\mathrm{CH}_{4}$ sorption isotherm model at $27^{\circ} \mathrm{C}$

\begin{tabular}{llllll}
\hline Depth $(\mathrm{m})$ & \multicolumn{2}{l}{ Freundlich isotherm } & & \multicolumn{2}{c}{ Langmuir isotherm } \\
\cline { 2 - 3 } \cline { 6 - 6 } & $1 / n$ & $K_{\mathrm{f}}$ & & $q_{\mathrm{m}}$ & \multicolumn{1}{c}{$K$} \\
\hline 580 & 0.9260 & 0.0181 & & 83.3333 & 0.000149 \\
520 & 1.3753 & 0.0008 & & 16.8067 & 0.000390 \\
500 & 1.8539 & 0.00003 & & 40.9836 & 0.000340 \\
450 & 1.1074 & 0.0040 & & 22.3713 & 0.000373 \\
400 & 0.8555 & 0.0228 & & 30.2114 & 0.000382 \\
\hline
\end{tabular}

models. Freundlich and Langmuir models were observed to be best fitted to the experimental values. This is due to the monolayer as well as multilayer sorption of gas in coal obtained from different depths of occurrence.
The constant for each model is shown in Tables 4 and 5. Constant, $q_{\mathrm{m}}$ obtained from Langmuir isotherm model indicates monolayer sorption process. Values of $1 / n$ and $K_{\mathrm{f}}$ were determined from Freundlich isotherm model. The values of $1 / n$ were found below 1 and above 1 indicating normal as well as cooperative sorption process. Thus, the monolayer as well as multilayer deposition of gas was observed in gas sorption process in coal. Temkin isotherm and D-R isotherm models were less fitted to the experimental values; therefore, the constants associated with the Temkin and D-R isotherms were not discussed in the results. The fitting of the Langmuir as well as Freundlich isotherm models to the experimental values is due to well-developed pores, pore size distribution and porosity in coal samples.

\section{Langmuir volume and pressure}

Langmuir volume and pressure are widely acceptable parameters in reservoir engineering. In a physical sense, the Langmuir volume constant $\left(V_{\mathrm{L}}\right)$ represents the maximum amount of gas that can be sorbed onto the given sample at infinite pressure. When pressure equals the Langmuir pressure constant $\left(P_{\mathrm{L}}\right)$, gas content is equal to half of $V_{\mathrm{L}}$. Thus, the Langmuir pressure constant represents the halfsaturation pressure, i.e. the pressure at which the coal holds one-half the maximum gas volume. Langmuir pressure and volume were determined for all coal samples as shown in 
Table 6. Langmuir volumes of $\mathrm{CO}_{2}$ and $\mathrm{CH}_{4}$ sorption were 11.11-20.53 and 9.5-13.29 cc/g at pressures $1.52-2.9$ and 3.59-5.32 MPa, respectively, at $27^{\circ} \mathrm{C}$. The Langmuir pressure and volume are important to determine the saturation level as well as critical desorption pressure in initial reservoir conditions.

\section{Effect of moisture content on sorption capacity of coal}

The moisture content of coal at varying depths was correlated with $\mathrm{CO}_{2}$ as well as $\mathrm{CH}_{4}$ sorption capacity and an increasing trend of gas sorption capacity with a decrease in moisture content was observed. Linear correlation with $R^{2}$ of 0.81 and 0.84 was observed between sorption capacity and moisture content reflecting a strong influence of moisture content on gas sorption capacity of coal (Fig. 8a, b).
Increase in gas sorption capacity with loss of moisture content is due to increases in porosity and gas sorption site in coal. The moisture in coal occupies more sorption sites and restricts the sorption of gas. Presence of moisture in coal is also responsible for matrix shrinkage and decrease in gas sorption capacity. The reduction in moisture content in coal facilitates more sorption site by producing more micro-pores and porosity in coal matrix.

\section{Effect of ash content on sorption capacity of coal}

Results obtained in experimentation reflect the reduced sorption capacity of both $\mathrm{CO}_{2}$ as well as $\mathrm{CH}_{4}$ with enrichment of ash content in coal. Linear correlation with $R^{2}$ of 0.93 and 0.97 was obtained between excess sorption amount and ash content reflecting the strong correlations between them (Fig. 9a, b). Decrease in gas sorption capacity of coal with
Table 6 Langmuir volume and pressure of coal samples at 27 ${ }^{\circ} \mathrm{C}$

\begin{tabular}{llllllll}
\hline Depth $(\mathrm{m})$ & \multicolumn{2}{l}{$\mathrm{CO}_{2}$ sorption } & & & $\mathrm{CH}_{4}$ sorption & \\
\cline { 2 - 3 } & $P_{\mathrm{L}}(\mathrm{MPa})$ & $V_{\mathrm{L}}(\mathrm{cc} / \mathrm{g})$ & $R^{2}$ & & $P_{\mathrm{L}}(\mathrm{MPa})$ & $V_{\mathrm{L}}(\mathrm{cc} / \mathrm{g})$ & $R^{2}$ \\
\hline 580 & 2.90 & 20.53 & 0.98 & & 5.32 & 13.29 & 0.99 \\
520 & 3.45 & 16.55 & 0.99 & & 4.59 & 12.3 & 0.99 \\
500 & 3.31 & 14.26 & 0.98 & 4.34 & 11.23 & 0.90 \\
450 & 2.38 & 10.02 & 0.99 & 4.22 & 8.97 & 0.99 \\
400 & 1.52 & 11.11 & 0.99 & 3.59 & 9.5 & 0.99 \\
\hline
\end{tabular}

Fig. 8 Effect of moisture content on sorption capacity of coal. a $\mathrm{CO}_{2}$ sorption and $\mathbf{b} \mathrm{CH}_{4}$ sorption
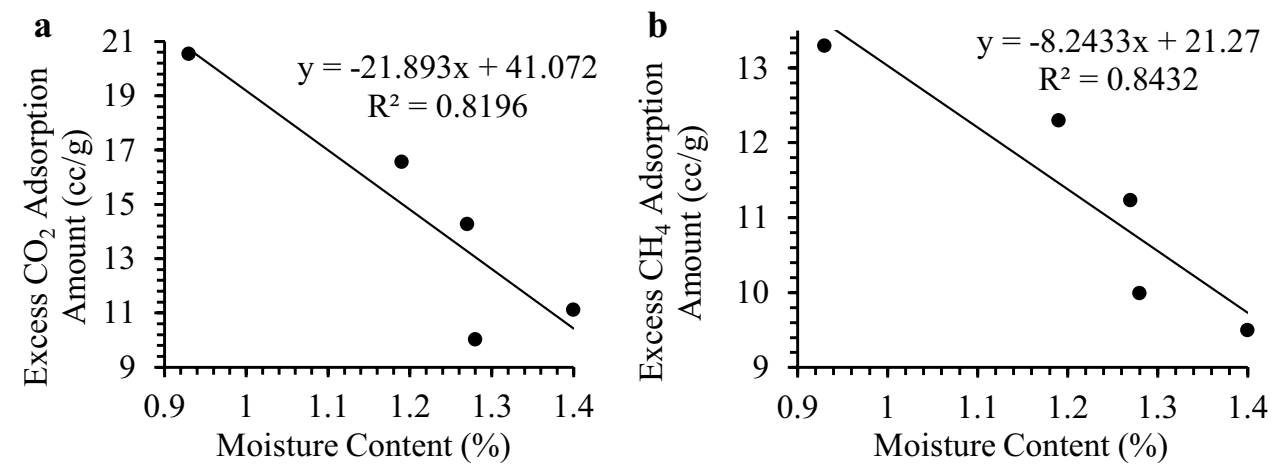

Fig. 9 Effect of ash content on sorption capacity of coal. a $\mathrm{CO}_{2}$ sorption and $\mathbf{b} \mathrm{CH}_{4}$ sorption
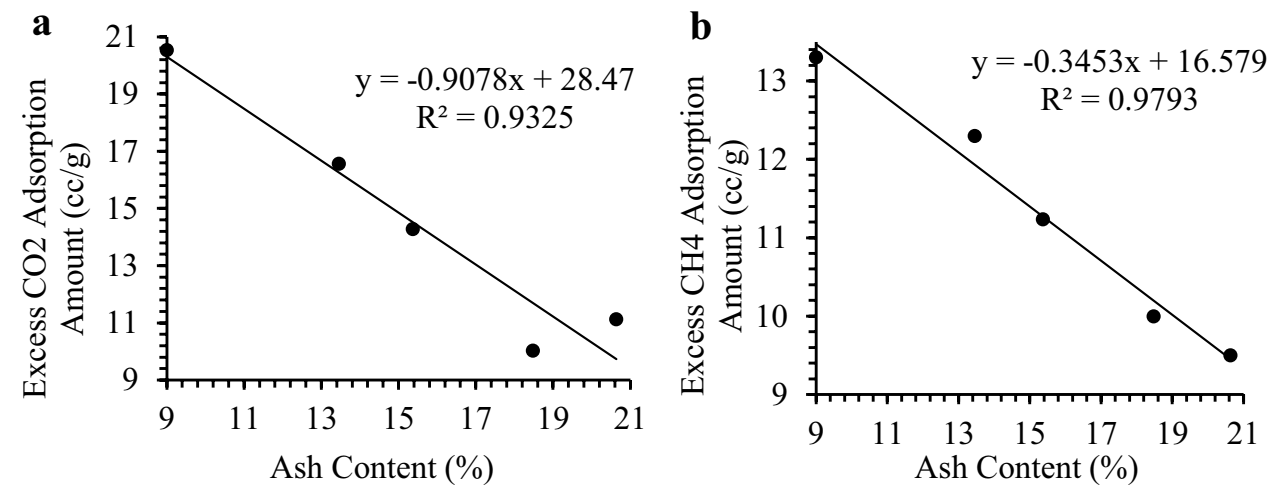


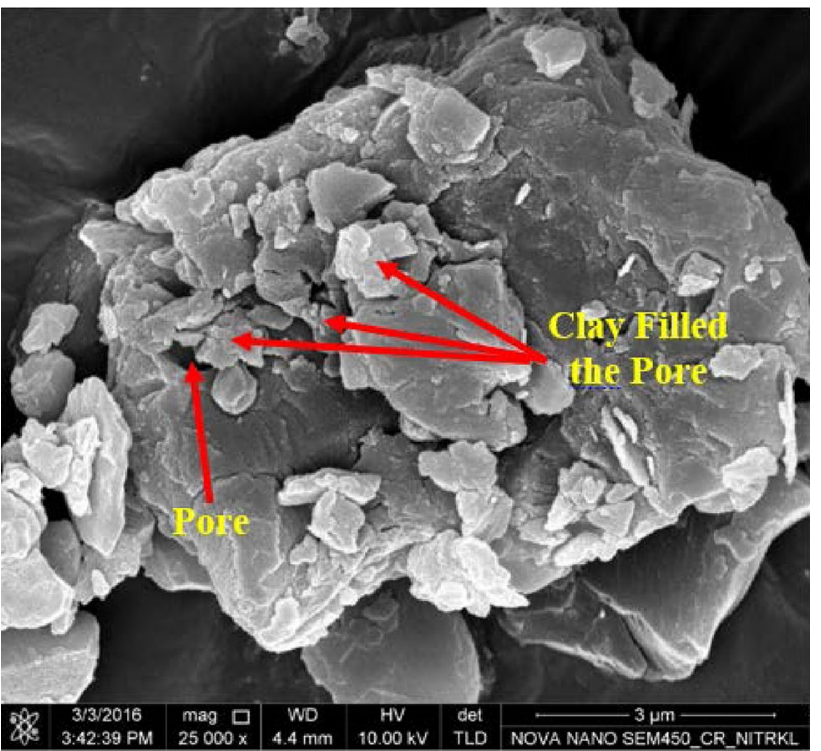

Fig. 10 FESEM image showing infilling of pores in coal sample

ash content is attributed to the infilling and blockage of pores, cleats and fracture system with inherent and extraneous mineral matter such as clays and carbonates in coal. The infilling of the pores is also indicated in the FESEM image shown in Fig. 10.

\section{Effect of fixed carbon (daf basis) on sorption capacity of coal}

Experimentally obtained sorption isotherm of both $\mathrm{CO}_{2}$, as well as $\mathrm{CH}_{4}$, was correlated with fixed carbon (daf basis) of coal samples (Fig. 11a, b). Linear and positive correlation with $R^{2} 0.90$ and 0.95 was obtained with $\mathrm{CO}_{2}$ as well as $\mathrm{CH}_{4}$ excess sorption capacity, respectively, reflecting strong influence of fixed carbon on sorption capacity of coal. Increased sorption capacity was observed with fixed carbon (daf basis). Increase in fixed carbon develops more micro- as well as meso-pores and facilitates gas sorption site in coal matrix (Ali et al. 2018).

\section{Effect of vitrinite reflectance on sorption capacity of coal}

The correlation was established with excess $\mathrm{CO}_{2}$ as well as $\mathrm{CH}_{4}$ sorption amount of coal and percentage of calculated vitrinite reflectance of coal (Fig 12a, b). Linear and positive correlation with $R^{2} 0.90$ and 0.93 was obtained with $\mathrm{CO}_{2}$ as well as $\mathrm{CH}_{4}$ excess sorption capacity, respectively, reflecting strong influence of vitrinite reflectance on sorption capacity of coal. Increased sorption capacity was observed with vitrinite reflectance. It is attributed to increase in porosity, pore size distribution, and specific pore surface area with increase
Fig. 11 Effect of fixed carbon (daf basis) on sorption capacity of coal. a $\mathrm{CO}_{2}$ sorption and $\mathbf{b}$ $\mathrm{CH}_{4}$ sorption
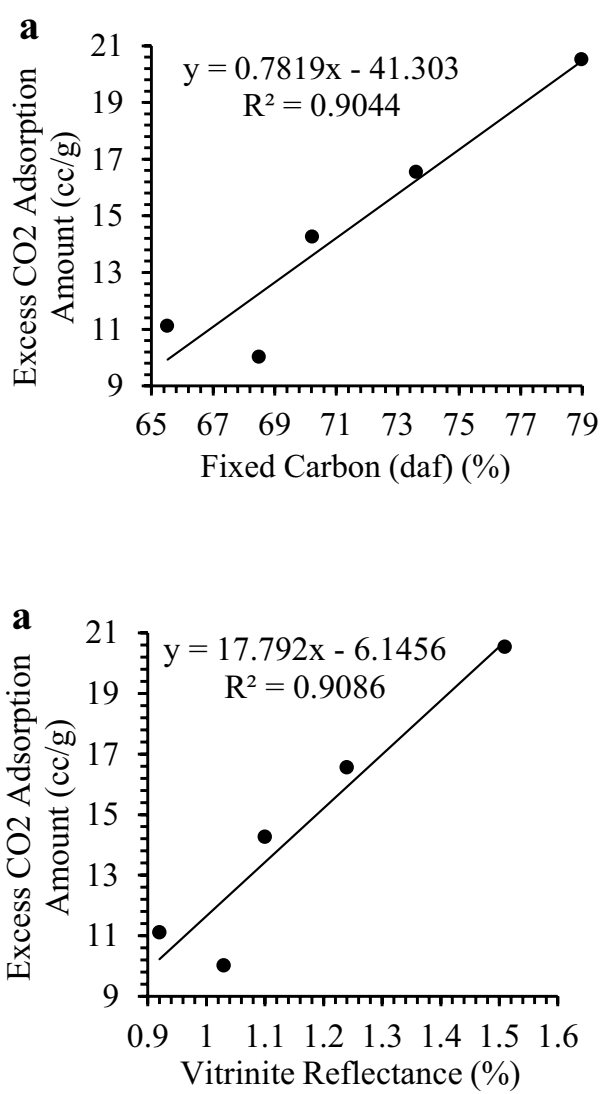
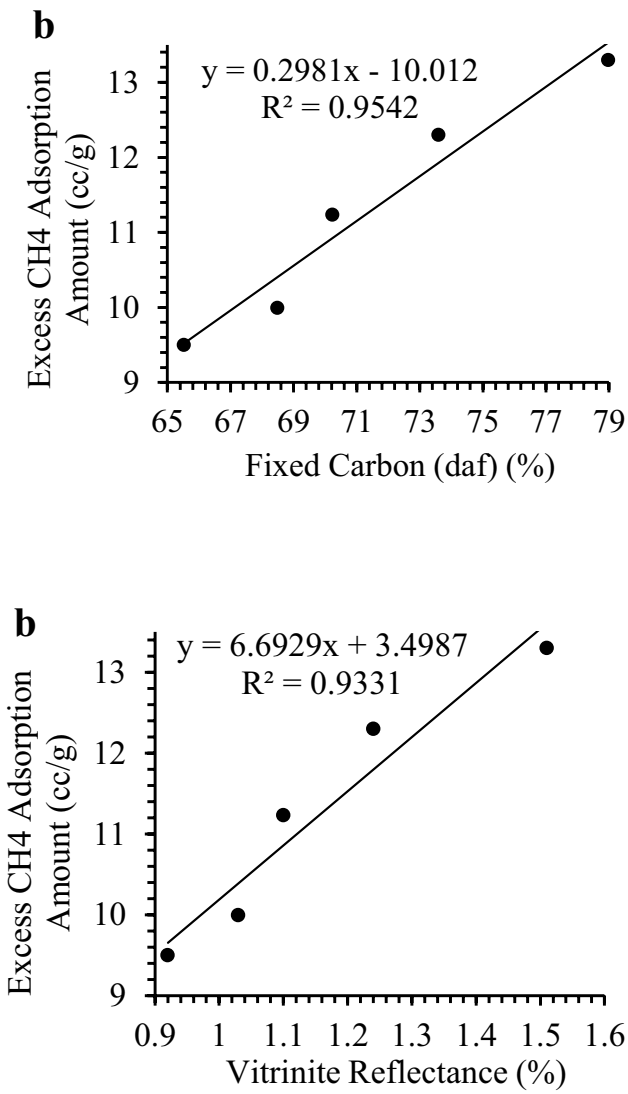

Fig. 12 Effect of vitrinite reflectance on sorption capacity of coal. a $\mathrm{CO}_{2}$ sorption and $\mathbf{b}$ $\mathrm{CH}_{4}$ sorption

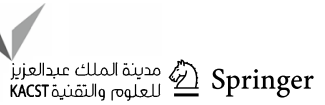

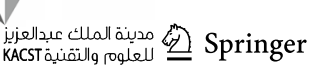


in vitrinite reflectance of coal (19, Suman and Harpalani 2019; Ali et al. 2018). The vitrinite reflectance value of the coal in study area indicates medium-ranking coal (mediumvolatile bituminous coal) which is favourable for meso- and macro-pores. These pores are favourable to sorption, diffusion, and migration of coal bed methane as well as injection of $\mathrm{CO}_{2}$ in coal matrix.

Thus, from the above investigation, it was observed that the depth of occurrence, molecular size of gases, affinity of gas towards coal, density, porosity, coal rank, etc. are the major controlling factors for the adsorption capacity of the coal.

\section{Conclusion}

The following conclusion is drawn from the observation of coal under investigation at Jharia coalfield (Moonidih area).

- Coal of study area was found in between medium and low volatile bituminous rank.

- Maximum sorption capacity of coal was observed to be $20.53 \mathrm{cc} / \mathrm{g}$ for $\mathrm{CO}_{2}$ and $13.29 \mathrm{cc} / \mathrm{g}$ for $\mathrm{CH}_{4}$ at $580 \mathrm{~m}$ depth.

- Carbon dioxide sorption capacity of coal was observed to be higher than that of the methane due to the higher density of $\mathrm{CO}_{2}$ and its interaction with coal than that with $\mathrm{CH}_{4}$. It is also due to variation in molecular diameter of $\mathrm{CO}_{2}(0.33 \mathrm{~nm})$ than $\mathrm{CH}_{4}(0.38 \mathrm{~nm})$.

- Monolayer as well as multilayer sorption of gas was exhibited by the coal samples at variable depths of occurence.

- Increase in gas sorption capacity was observed with fixed carbon, vitrinite reflectance and decrease in ash content and moisture content, respectively.

Acknowledgements The authors acknowledge the financial assistance provided by SERB, DST, vide Approval no: SB/S4/ES-697/2013.

Open Access This article is distributed under the terms of the Creative Commons Attribution 4.0 International License (http://creativeco mmons.org/licenses/by/4.0/), which permits unrestricted use, distribution, and reproduction in any medium, provided you give appropriate credit to the original author(s) and the source, provide a link to the Creative Commons license, and indicate if changes were made.

\section{References}

Ali K, Richard S, Grigore M, Sokolova A (2018) Gas sorption capacity, gas sorption rates and nanoporosity in coals. Int J Coal Geol 200:77-86
Buscha A, Gensterblumb Y (2011) CBM and $\mathrm{CO}_{2}$-ECBM related sorption processes in coal: a review. Int J Coal Geol 87:49-71

Chandra K (1950) Alternative hydrocarbon resources in the next millennium. Geohorizons 2:1-12

Chen KC, Irawan S, Sum CW, Tunio SQ (2011) Preliminary study on gas storage capacity and gas-in-place for CBM potential in Balingian coalfield: Sarawak Malaysia. Int J Appl Sci Technol 1:82-94

Daniel RJK, Bustin M, R (2007) Impact of mass balance calculations on adsorption capacities in microporous shale gas reservoirs. Fuel 86:2696-2706

Deng H, Tang D, Liu S, Xu H, Tao S (2015) Characterization of mineral composition and its influence on microstructure and sorption capacity of coal. J Nat Gas Sci Eng 25:46-57

Diessel CFK (1992) Coal-bearing depositional systems. Springer, Berlin, p 721

Garnier C, Finqueneisel G, Zimny T, Pokryszka Z, Lafortune S, Defossez PDC, Gaucher EC (2011) Selection of coals of different maturities for $\mathrm{CO}_{2}$ storage by modelling of $\mathrm{CH}_{4}$ and $\mathrm{CO}_{2}$ adsorption isotherms. Int J Coal Geol 87:80-86

Gensterblum Y, Hemert PV, Billemont P, Battistutta E, Busch A, Krooss BM, Weireld GD, Wolf KHAA (2010) European interlaboratory comparison of high pressure $\mathrm{CO}_{2}$ sorption isotherms II: natural coals. Int J Coal Geol 84:115-124

Ghosh S, Jha P, Vidyarthi AS (2014) Unraveling the microbial interactions in coal organic fermentation for generation of methane-a classical to metagenomics approach. Int J Coal Geol $125: 36-44$

Gruszkiewicz MS, Naney MT, Blencoe JG, Cole DR, Pashin JC, Carroll RE (2009) Adsorption kinetics of $\mathrm{CO}_{2}, \mathrm{CH}_{4}$, and their equimolar mixture on coal from the Black Warrior Basin, WestCentral Alabama. Int J Coal Geol 77:23-33

Guo HX (2003) Applied chemical engineering kinetics, vol 16. Chem Ind Press, Beijing, pp 12-18

Hernandez GA, Bello RO, Vay DAM (2006) Evaluation of the technical and economic feasibility of $\mathrm{CO}_{2}$ sequestration and enhanced coalbed-methane recovery in Texas low-rank coals. In: Proceedings of the SPE Gas technology symposium. Mature fields to new frontiers. 515-530

Ishaq UM, Bijaksana S, Nurhandoko BEB (2009) Porosity and fracture pattern of coal as CBM reservoir. In: Proceedings of the 3rd Asian physics symposium (APS 2009)

Kim HJ, Shi Y, He J, Lee HH, Lee CH (2011) Adsorption characteristics of $\mathrm{CO}_{2}$ and $\mathrm{CH}_{4}$ on dry and wet coal from subcritical to supercritical conditions. Chem Eng J 171:45-53

Maphala T (2012) Effects of carbon dioxide storage in coal on the physical 1 and chemical properties of coal. In: Ph.D thesis submitted in Faculty of Engineering and the Built Environment. University of the Witwatersrand. Johannesburg

Mares ET, Radliński AP, Moore TA, Cookson D, Ilavsky TPJ, Klepp $\mathrm{J}$ (2009) Assessing the potential for $\mathrm{CO}_{2}$ adsorption in a subbituminous coal, Huntly Coalfield, New Zealand, using small angle scattering techniques. Int J Coal Geol 77:54-68

Pagnier HJM, Bergen FV, Kreft E, Meer LGH, Simmelink HJ (2005) Field experiment of ECBM- $\mathrm{CO}_{2}$ in the upper Silesian Basin of Poland (RECOPOL). In: Proceedings of the 67th European Association of Geoscientists and Engineers. EAGE conference and exhibition. 3013-3015

Prusty BK (2008) Sorption of methane and $\mathrm{CO}_{2}$ for enhanced coal bed methane recovery and carbon dioxide sequestration. J Nat Gas Chem 17:29-39

Rice DD (1993) Composition and origins of coalbed gas. Am Assoc Pet Geol Stud Geol 38:159-184

Robertson PE (2010) Enhanced coal bed methane recovery and $\mathrm{CO}_{2}$ sequestration in the Powder River Basin. Idaho National Laboratory Idaho Falls, Idaho

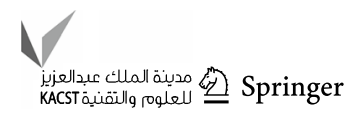


Saghaf A (2010) Potential for ECBM and $\mathrm{CO}_{2}$ storage in mixed gas Australian coals. Int J Coal Geol 82:240-251

Saikia K, Sarkar BC (2013) Coal exploration modelling using geostatistics in Jharia coalfield: India. Int J Coal Geol 112:36-52

Seidle JP (2000) Reservoir engineering aspects of $\mathrm{CO}_{2}$ sequestration in coals. In: Proceedings of the SPE/CERI Gas technology symposium. Alberta. Canada

Shi JQ, Durucan S (2005) $\mathrm{CO}_{2}$ storage in deep unminable coal seams. Oil Gas Sci Technol 60:547-558

Song Y, Xing W, Zhang Y, Jian W, Liu Z, Liu S (2015) Adsorption isotherms and kinetics of carbon dioxide on Chinese dry coal over a wide pressure range. Int J Adsorpt 21:53-65

Sripada P, Khan MM, Ramasamy S, Trivedi J, Gupta R (2018) Influence of coal properties on the $\mathrm{CO}_{2}$ adsorption capacity of coal gasification residues. Energy Sci Eng 6:321-335

Stevens SH, Spector D, Riemer P (1998) Enhanced coalbed methane recovery using $\mathrm{CO}_{2}$ injection. Worldwide resource and $\mathrm{CO}_{2}$ sequestration potential. In: Proceedings of the 6th international oil \& gas conference and exhibition in China (IOGCEC '98), pp 489-501

Suman S, Harpalani S (2019) Anisotropy of coal at various scales and its variation with sorption. Int J Coal Geol 201:14-25
Vishal V, Ranjith P, Singh T (2015) An experimental investigation on behaviour of coal under fluid saturation, using acoustic emission. J Nat Gas Sci Eng 22:428-436

Wang Z, Li Y, Liu H, Zeng F, Guo P, Jiang W (2017) Study on the adsorption, diffusion and permeation selectivity of shale gas in organics. Energies 10:142

Zhang L, Ren TX, Aziz N (2013) A study of laboratory testing and calculation methods for coal sorption isotherms. J Coal Sci Eng 19:193-202

UGI Energy Ministry of Power, Central Electricity Authority New Delhi 2017: Coal and Gas Power. 1-52

International Energy Agency (IEA analysis of gas market report): market analysis and forecasts 2014. 1-20

Publisher's Note Springer Nature remains neutral with regard to jurisdictional claims in published maps and institutional affiliations. 